\title{
Genetic Characterization Based on RAPD-PCR in Cultured Strains of Clarias gariepinus (Siluriformes: Clariidae)
}

\author{
Folasade Adesola Ola-Oladimeji $\left.{ }^{1, *}{ }^{(}\right)$, Michael Olufemi Awodiran ${ }^{2}$, Victor \\ Folorunso Olaleye ${ }^{2}$, Joel Idowu Awopetu ${ }^{2}$
}

${ }^{1}$ Ekiti State University, Department of Zoology and Environmental Biology, P.M.B. 5363, Ado-Ekiti, Ekiti State, Nigeria. ${ }^{2}$ Obafemi Awolowo University, Department of Zoology, P.M.B. 13, Ile-Ife, Osun State, Nigeria.

\section{Article History}

Received 30 April 2020

Accepted 26 August 2020

First Online 07 September 2020

\section{Corresponding Author \\ Tel.: +2348034797058 \\ E-mail: \\ folasade.majolagbe@eksu.edu.ng}

\section{Keywords \\ Polymerase \\ Variability \\ Population \\ Dendrogram \\ Primers}

\begin{abstract}
The genetic polymorphisms of catfish populations collected from four fish farms in four Southwestern states of Nigeria were determined by Randomly Amplified Polymorphic DNA Polymerase Chain Reaction technique. This was to characterize the strains genetically and provide information on the studied catfish. Following standard procedures, polymerase chain reaction was performed by mixing $15 \mu \mathrm{l}$ reaction mixture containing FIREPOL ${ }^{\circ}$ Taq DNA polymerase, $\mathrm{MgCl}_{2}$, dNTPs, distilled water, dyes and glycerol, with $1.0 \mu \mathrm{I}$ DNA sample of 16-week old $C$. gariepinus strains using OPA03, OPA04, OPC02, OPB08, OPC11, OPG16, OPG19 and OPA19 primers. A sum of 1708 loci having 3072 bands was amplified in all the samples. The RAPD analysis revealed significant genetic variability $(P<0.05)$ among the four sampled populations. The unweighted pair group method with average (UPGMA) dendrogram based on Nei's unbiased genetic distance matrix separated the Clarias gariepinus populations into two clades. The first clade was made up of populations from Ibadan and Abeokuta while the second clade consisted of populations from Ado-Ekiti and lle-Ife. Thus, it is imperative to determine the genetic variation and population structure of the stocks of $C$. gariepinus in advance before commencing on breeding programmes.
\end{abstract}

\section{Introduction}

Clarias gariepinus is a desired aquaculture fish in Nigeria. It belongs to the Kingdom Animalia, Phylum Chordata, Class Actynopterigii, Order Siluriformes and Family Clariidae (Freyhof, 2014). It is a member of the most diverse genus, Clarias (Legendre, Teugels, Cauty, \& Jalabert, 1992). It has a helmet-like head and scaleless, bony elongated body with long dorsal and anal fins. It is a typical air-breathing catfish that has a broad terminal mouth with four pairs of barbels. Its colour varies dorsally from dark to light brown and is often speckled with shades of olive and grey while the lower side is pale cream to white (Skelton, 2001).

Since this fish is a widely accepted species, scientific studies on it cannot be over-emphasised. Even though traditional methods like morphological (Ola-
Oladimeji, et al., 2017; Okomoda, Koh, Hassan, Amornsakun, \& Shahreza, 2018) and biochemical studies ((Ola-Oladimeji, Idowu, Adewumi, \& Fafowora, 2018) which have been reported to be laborious and time-consuming (Coulo, Vessen, Hofstra, \& Huisveld, 1994) and are less efficient in detecting differences in traits have been carried out on the fish, some studies have also been done on its genetic management like hybridization (Ola-Oladimeji, 2015) and cytogenetic techniques such as polyploidy, androgenesis and gynogenesis (Dunham, 2011; Olaniyi \& Omitogun, 2012; Karami et al., 2016; Okomoda et al., 2020).

Recently, the application of molecular primers based on the relative difference in deoxyribonucleic acid (DNA) sequences between individuals has been shown to detect more polymorphisms than morphological and protein-based markers. Molecular primers are also used 
to study genomes, isolate genes, locate genes on chromosomes, determine gene expression, conduct gene-linkage maps, study the molecular mechanisms of performance, conduct population genetics analysis and apply marker-assisted selection (Liu \& Dunham, 1998).

It is well-known that all inherited characteristics or traits are under genetic control; consequently, various methods have been developed for genetic analysis of populations. The molecular analyses are the most direct and potent, and these were enhanced by the development of the Polymerase Chain Reaction (PCR). The PCR depends on the ability to alternately denature (melt) double-stranded DNA molecules and renature (anneal) complementary single strands in a controlled fashion (Lodish et al., 2016). The variations in the size of a gene can then be detected by a change in the size of the PCR product which can be determined by using gel electrophoresis (Dale \& Park, 2004).

According to Ikpeme et al. (2015), genetic analysis can be used to determine variation. Danish \& Singh (2018) also found that significant population differentiation which indicated some degree of intraand inter-population genetic variations existed in two populations of Clarias batrachus. This was suggested to be due to the difference in habitat and breeding strategies between the two populations. One of several markers used in the analyses is Random Amplified Polymorphic DNA (RAPD). This technique uses short primers of arbitrary nucleotide sequence to access and reproducibly amplify random segments of genomic DNA (from a wide variety of species) to reveal polymorphisms among the amplification products which are useful as genetic markers and can be detected through examination of an ethidium bromide-stained agarose gel (Williams, Kubelik, Livak, Rafalski, \& Tingey, 1990). The RAPD markers are for various uses in the detection of genetic diversity in population genetics (Zheng et al., 2019) and it was used to characterize cultured strains of C. gariepinus in this study.

A few studies (Saad, Hanafi, Essa, Guerges, \& Ali, 2009; Popoola, Fasakin, \& Awopetu, 2014; Ikpeme et al., 2015) have been reported on genetic similarity and diversity of different populations of $C$. gariepinus. In spite of these, information on the genetic characterization of the fast-and slow-growing strains of cultured C. gariepinus using Randomly Amplified Polymorphic DNA is yet to be provided. Therefore, it is important to study these strains of catfish more because fish farmers are faced with challenges of managing runts during culture and these have reduced their productivity and income.

This study aims to characterize the cultured strains of C. gariepinus in Southwestern Nigeria genetically using Random Amplified Polymorphic DNA (RAPD) markers for management and preservation of its genetic resources in future studies.

\section{Materials and Methods}

\section{Identification and Collection of Fish Specimens}

Forty (40) eight-week-old fast- and 40 slow-growing strains of $C$. gariepinus were identified, collected from four selected farms in four Southwestern states of Nigeria (Figure 1) for comparison and to obtain a better result. The two strains were obtained by selecting and
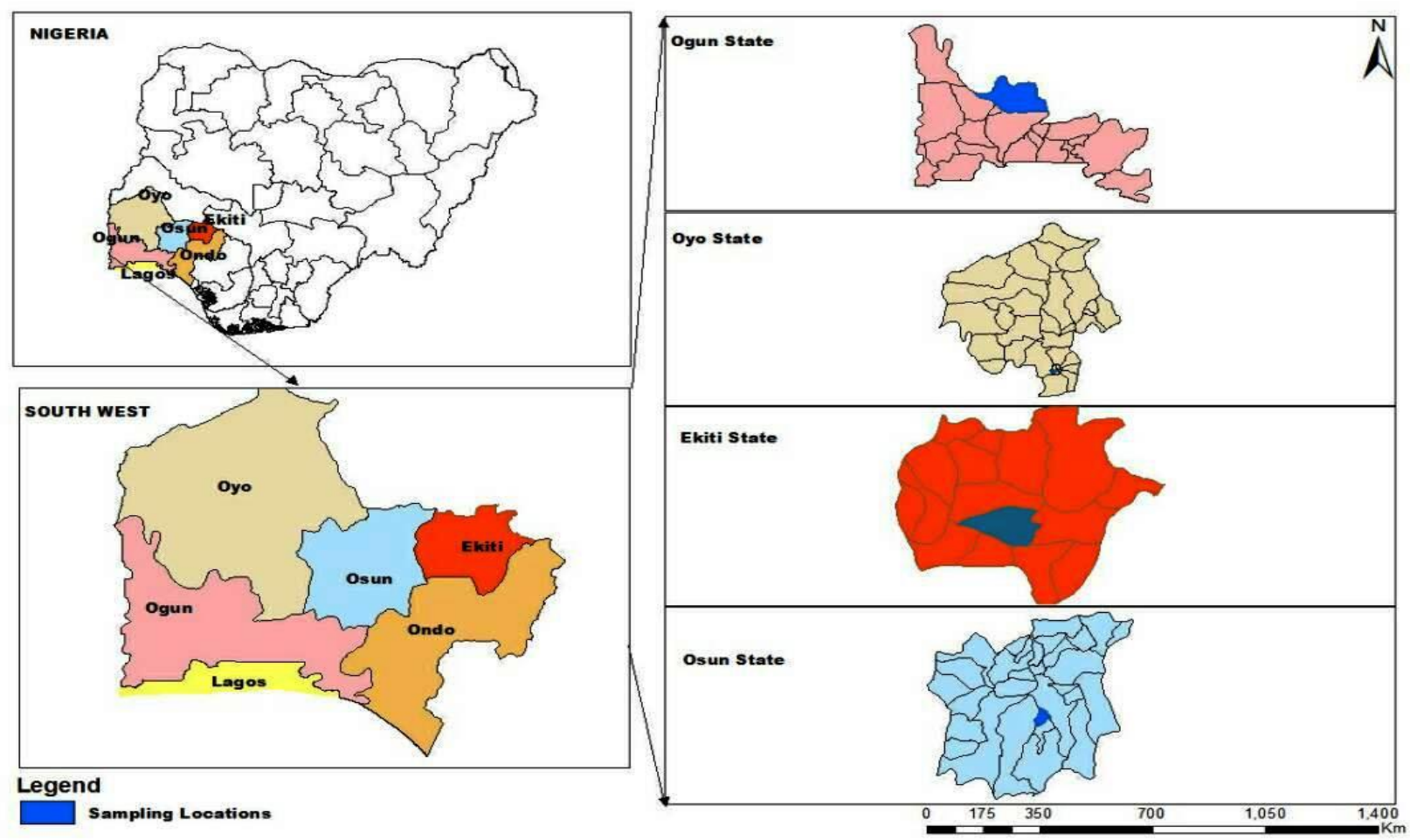

Figure 1: Map of Nigeria with colour-coded states where the $C$. gariepinus juveniles were collected. 
separating the shooters from the runts after two weeks of rearing. Samples were collected from the following selected locations; the Teaching and Research Farm, Federal University of Agriculture, Abeokuta (FUNAAB) (7०09' 20" N \& $\left.3^{\circ} 20^{\prime} 42^{\prime \prime} \mathrm{E}\right)$; Sun Fish Farm, Ibadan, (7 $\left.22^{\prime} 39^{\prime \prime} \mathrm{N} \& 3^{\circ} 54^{\prime} 21^{\prime \prime} \mathrm{E}\right)$; Ade Aquaculture Centre, AdoEkiti, ( $\left.7^{\circ} 37^{\prime} 23^{\prime \prime} \mathrm{N} \& 5^{\circ} 13^{\prime} 15^{\prime \prime} \mathrm{E}\right)$; and Edens Fish Farm, Ile-Ife, ( $\left.7^{\circ} 28^{\prime} 0^{\prime \prime} \mathrm{N} \& 4^{\circ} 34^{\prime} 0^{\prime \prime} \mathrm{E}\right)$. At the sampling sites, each of the fast-and slow-growing strains was separated appropriately and the fish were raised in different tanks simultaneously at Edens Fish Farm, Ile-Ife.

\section{Blood Sample Collection for DNA Extraction}

Genomic DNA was extracted from the blood of each of the individual fish ( 40 in total) from the selected groups after rearing using NORGEN Blood Genomic DNA Isolation Kit (NORGEN, Biotechnology Corporation, Canada, 2014). The extraction was performed according to El-Mogy, Simkin, and Haj-Ahmad (2016), using spin column chromatography method.

\section{RAPD and Electrophoresis}

DNA amplification was done using RAPD (OPA03, OPA04, OPC02, OPB08, OPC11, OPG16, OPG19 and OPA19) according to standard but a modified method of Williams et al. (1990). Table 1 shows the characterization of the primers used including the primer sequences and annealing temperatures. The amplified products $(8 \mu \mathrm{l})$ of each sample were separated by electrophoresis in $1 \%$ agarose gels buffered with $1 \mathrm{X}$ TAE and the polymorphisms among the amplification products were detected by staining with $15 \mu \mathrm{l}$ of 0.5 $\mu \mathrm{g} / \mathrm{mL}$ Ethidium Bromide. A PCRSizer 100 bp DNA ladder (100bp - 1000bp) (Norgen Biotek Corporation, Canada) was electrophoresed alongside the RAPD reactions as molecular weight marker. Electrophoresis was run at $100 \mathrm{~V}$ for 2.5 hours. Finally, the DNA bands were examined under Ultra-Violet (UV) transilluminator system (ZENITH, India), and the stained gels were photographed and saved on the computer for further analysis.

\section{Statistical Analysis}

The results obtained after rearing the catfish were analysed with Descriptive statistics, Analysis of variance
(ANOVA) and Duncan's multiple range test (DMRT) using IBM SPSS Statistics (Version 22, 2013) software.

\section{Scoring of RAPD Bands}

The RAPD bands were scored from the photomicrographs of the gel as binary data using GelQuest-DNA Fragment Analysis Software, Version 3.2.1 (@2010 SequentiX-Digital DNA Processing, Germany). A single data matrix was constructed pooling the binary data $(1 / 0)$ for all the primers.

\section{Data Analyses for RAPD}

GenAlEx 6.502 genetic software (Peakall \& Smouse, 2006; 2012) was used to analyse the data generated to compute the number of different bands, analysis of molecular variance (AMOVA), Nei's genetic identity and Nei's genetic distances. Nei`s genetic distances were calculated for all population pairs to construct a phylogenetic tree (Unweighted pair group method with average dendrogram) using MEGA evolutionary genetic analysis software (Version 7.0.21, 2018).

\section{Results}

\section{Length and Weight Traits of $C$. gariepinus}

The mean total length and body weight of the two strains of $C$. gariepinus used for DNA analysis are shown in (Table 2). The mean total length and body weight were significantly higher at $\mathrm{P}<0.05$ in the fast-growers than in the slow-growing strains.

\section{Profile of RAPD Markers}

Plate 1 shows the representative agarose gel electrophoretic profile of RAPD using OPG16 primer. For all the primers used, a sum of 1708 loci having 3072 bands was amplified in all the samples. The fast-growing catfish had 1522 bands while slow-growing fish showed 1550 bands (Table 3). In Table 4, the lowest number of private bands (85) among the slow-growing population was recorded in the Ibadan population, while among the fast-growers; the population from Abeokuta had the least (74). The analysis showed that the number of locally common bands were correspondingly higher in

Table 1. Characterization of RAPD primers used in the analysis, including primer sequences and annealing temperatures (Ta ( $\left.{ }^{\circ} \mathrm{C}\right)$ )

\begin{tabular}{llc}
\hline Primers & Sequences & Ta $\left({ }^{\circ} \mathrm{C}\right)$ \\
\hline OPA03 & 5'AGTCAGCCAC3' & 37.0 \\
OPA04 & 5'AATCGGGCTG3' & 35.1 \\
OPC02 & 5'GTGAGGCGTC3' & 37.6 \\
OPB08 & 5'GTCCACACGG3' & 37.3 \\
OPC11 & 5'AAAGCTGCGG3' & 36.9 \\
OPG16 & 5'AGCGTCCTCC3' & 38.8 \\
OPG19 & 5' GTCAGGGCAA3' & 34.7 \\
OPA19 & 5'CAAACGTCGG3' & 32.2 \\
\hline
\end{tabular}


Table 2. Differences in length and weight between the two strains of $C$. gariepinus used for DNA analysis

\begin{tabular}{lcc}
\hline Strains & Total length $(\mathrm{cm})$ & Body weight $(\mathrm{g})$ \\
\hline Fast-growing C. gariepinus & $40.44^{\mathrm{a}} \pm 0.58$ & $466.66^{\mathrm{a}} \pm 18.66$ \\
Slow-growing C. gariepinus & $21.55^{\mathrm{b}} \pm 0.50$ & $81.89^{\mathrm{b}} \pm 5.62$ \\
\hline
\end{tabular}

*Means in the same column superscripted by different letters differed significantly $(\mathrm{P}<0.05)$

Table 3. Number of bands and loci

\begin{tabular}{|c|c|c|c|c|c|c|c|c|c|}
\hline Population type & & & & Primers & & & & & Total \\
\hline \multicolumn{10}{|l|}{ Slow-growers } \\
\hline & OPA03 & OPA04 & OPA19 & ОРВ08 & OPC02 & OPC11 & OPG16 & OPG19 & \\
\hline$S A B$ & 34 & 36 & 31 & 36 & 37 & 41 & 52 & 40 & 307 \\
\hline SIB & 27 & 32 & 35 & 45 & 29 & 48 & 42 & 38 & 296 \\
\hline SAD & 114 & 46 & 125 & 36 & 43 & 45 & 42 & 5 & 456 \\
\hline \multirow[t]{2}{*}{ SIL } & 126 & 49 & 137 & 38 & 37 & 36 & 44 & 24 & 491 \\
\hline & & & & & & & & & 1550 \\
\hline \multicolumn{10}{|l|}{ Fast-growers } \\
\hline FAB & 32 & 30 & 34 & 46 & 47 & 0 & 43 & 33 & 265 \\
\hline FIB & 26 & 34 & 34 & 45 & 30 & 46 & 47 & 40 & 302 \\
\hline FAD & 128 & 42 & 133 & 42 & 37 & 49 & 46 & 0 & 477 \\
\hline FIL & 106 & 46 & 125 & 45 & 41 & 49 & 47 & 19 & 478 \\
\hline Total & & & & & & & & & 1522 \\
\hline Total Number of loci & 286 & 188 & 304 & 193 & 181 & 205 & 213 & 138 & 1708 \\
\hline
\end{tabular}

Table 4. Band patterns obtained after band scoring across the populations

\begin{tabular}{lcc}
\hline Population & No. private bands & No. shared bands $(<=25 \%)$ \\
\hline Slow-growers & & 102 \\
SAB & 94 & 119 \\
SIB & 85 & 139 \\
SAD & 123 & 154 \\
SIL & 132 & 92 \\
Fast-growers & & 92 \\
FAB & 74 & 164 \\
FIB & 96 & 150 \\
FAD & 111 & \\
FIL & 136 & \\
\hline ND. private
\end{tabular}

No. private bands $=$ No. of bands unique to a single population

No. shared bands $(<=\mathbf{2 5 \%})=$ No. of common bands (freq. $>=5 \%$ ) found in $25 \%$ or fewer populations

$\mathbf{S A B}=$ Slow-growers Abeokuta, SIB= Slow-growers Ibadan, SAD= Slow-growers Ado-Ekiti, SIL= Slow-growers Ile-Ife. FAB=Fast-growers Abeokuta, FIB= Fast-growers Ibadan, FAD= Fast-growers Ado-Ekiti, FIL= Fast-growers Ile-Ife

the slow-growing populations from across locations than those of the fast-growers. The only exception recorded was in the Ado-Ekiti population where the slow-growers had lower (139) locally common bands than the fast-growers (164).

Plate 1(A and B) Representative agarose gel electrophoretic profile of RAPD using OPG16 primer for adult $C$. gariepinus (Figure 2)

\section{Population Differentiation and Structure}

The Analysis of Molecular Variance, AMOVA showed the significance levels of genetic variability among regions, $\Phi_{\mathrm{PR}}$ and among regions corrected for bias $\Phi_{P R}^{\prime}$ were 0.01 . Most of the genetic diversity occurred within populations (92\%) while the variability among regions and populations contributed $7 \%$ and $1 \%$ respectively (Figure 3 , Table 5 ).

The value of inter-population Nei's genetic identity was found least (0.963) between slow-growers from Ibadan and fast-growers from Ado-Ekiti. The highest $(0.985)$ value was recorded between the strains from Abeokuta (Table 6). Also, the unweighted pair group method with average (UPGMA) dendrogram based on Nei's unbiased genetic distance matrix (Nei, 1972) performed according to RAPD analysis separated the four catfish populations sampled into two clades. The first clade was formed by populations sampled from 
Ibadan and Abeokuta while the second was formed by populations sampled from Ado-Ekiti and Ile-Ife (Figure 4).

\section{Discussion}

This study has shown the existence of genetic variability and relatedness among and within $C$. gariepinus populations from four hatcheries in SouthWestern Nigeria. The catfish have shown some similarities with regards to the number of bands shared in common and variations have also been observed as a result of some fragments present in one group and absent in another in the locally common bands.

According to Awodiran and Afolabi (2018), genetic variations, which are known as 'the raw materials for evolution,' are of importance in the survival of species. There is a need to deliberately introduce new breeds into the cultured populations in order to enhance the evolutionary potentials of these populations. To avoid a vicious cycle, the introduction of these new genotypes must be done methodically, because outbreeding depression is an impending risk if the genetic distance between the populations and the new breeds is too large.

The high genetic identity observed in this research may be because these catfish are from cultured environments. These were comparable with Popoola et al. (2014) and Ikpeme et al. (2015) who worked on $C$. gariepinus. While Ikpeme et al. (2015) reported that as genetic distance increased, genetic identity narrowed between the wild and the cultured species, Popoola et al. (2014) reported that the percentage of genetic identity and genetic distance of RAPD-PCR profile among six populations of wild and cultured $C$. gariepinus ranged from $74.6 \%$ to $83.5 \%$ and from 0.180 to 0.293
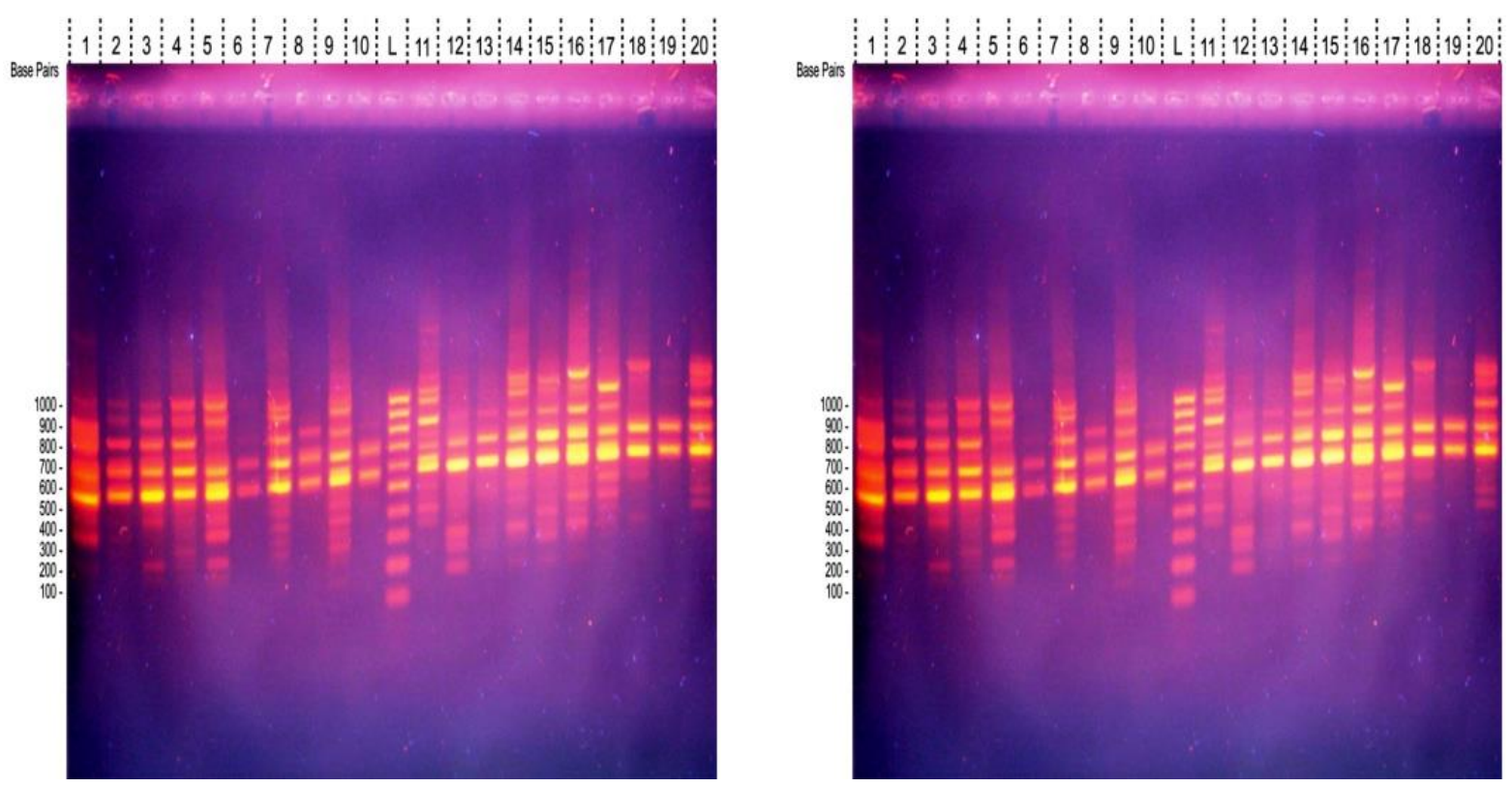

Figure 2. Plate $1(A$ and $B)$ : Representative agarose gel electrophoretic profile of RAPD using OPG16 primer for adult $C$. gariepinus.

Lanes 1-5= FAB, 6-10= SAB, L = DNA ladder, 11-15=FIB, 16-20=SIB. Lanes 21-25= FAD and 26-30= SAD, L = DNA ladder, lanes 31-35=FIL and 36$40=\mathrm{SIL}$.

$\mathbf{F A B}=$ Abeokuta fast-growers, $\mathbf{S A B}=$ Abeokuta slow-growers, $\mathbf{F I B}=$ Ibadan fast-growers, $\mathbf{S I B}=$ Ibadan slow-growers, $\mathbf{F A D}=$ Ado-Ekiti fast-growers, $\mathbf{S A D}=$ Ado-Ekiti slow-growers, $\mathbf{F I L}=\| l e-I f e$ fast-growers, $\mathbf{S I L}=\| l e-I f e$ slow-growers.

Table 5. Analysis of molecular variance (AMOVA) showing the partitioning of genetic variation among regions and populations, and within populations of $C$. gariepinus studied

\begin{tabular}{|c|c|c|c|c|c|}
\hline Source of variation & Est. var. & $\%$ & DPR & Ф'PR & $\mathrm{P}($ rand $>=$ data $)$ \\
\hline Among Regions & 5.878 & $7 \%$ & & & \\
\hline Among Populations & 1.097 & $1 \%$ & & & \\
\hline Within Population & 83.938 & $92 \%$ & & & \\
\hline Total & 90.913 & $100 \%$ & 0.01 & 0.01 & 0.0001 \\
\hline
\end{tabular}

Est. var. = Estimate of variance

$\%=$ Percentage of total variation

ФPR = Genetic variability among regions

Ф'PR = Genetic variability among regions corrected for bias

$\mathbf{P}($ rand $>=$ data $)=$ Level of significance 


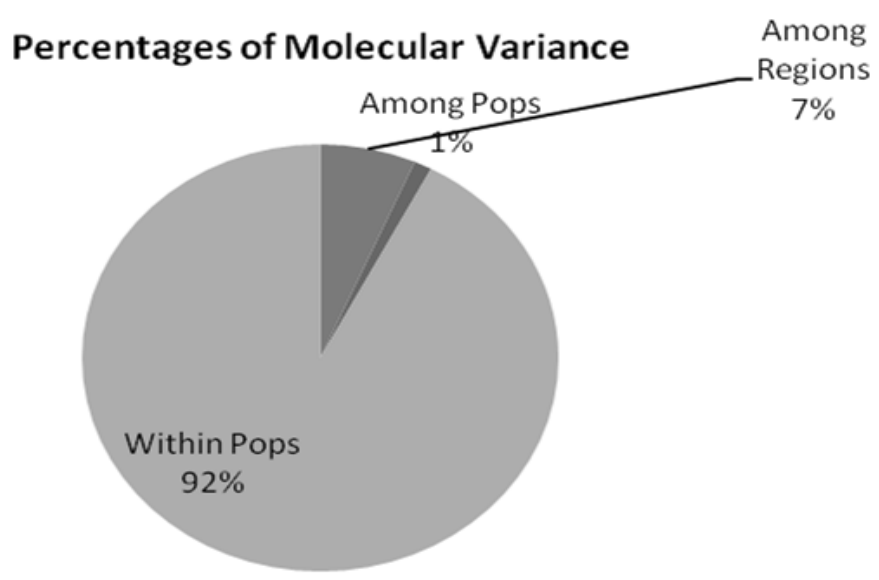

Figure 3. Sources and proportion of molecular variance: Input as binary distance matrix.

Table 6. Pairwise population matrix of Nei's genetic identity obtained after analysing RAPD bands

\begin{tabular}{|c|c|c|c|c|c|c|c|c|}
\hline FAB & SAB & FIB & SIB & FAD & SAD & FIL & SIL & \\
\hline 1.000 & & & & & & & & $\overline{F A B}$ \\
\hline 0.985 & 1.000 & & & & & & & $S A B$ \\
\hline 0.984 & 0.984 & 1.000 & & & & & & FIB \\
\hline 0.983 & 0.983 & 0.982 & 1.000 & & & & & SIB \\
\hline 0.966 & 0.964 & 0.966 & 0.963 & 1.000 & & & & FAD \\
\hline 0.970 & 0.969 & 0.969 & 0.968 & 0.971 & 1.000 & & & SAD \\
\hline 0.969 & 0.968 & 0.968 & 0.967 & 0.967 & 0.971 & 1.000 & & FIL \\
\hline 0.968 & 0.966 & 0.967 & 0.965 & 0.966 & 0.970 & 0.971 & 1.000 & SIL \\
\hline
\end{tabular}

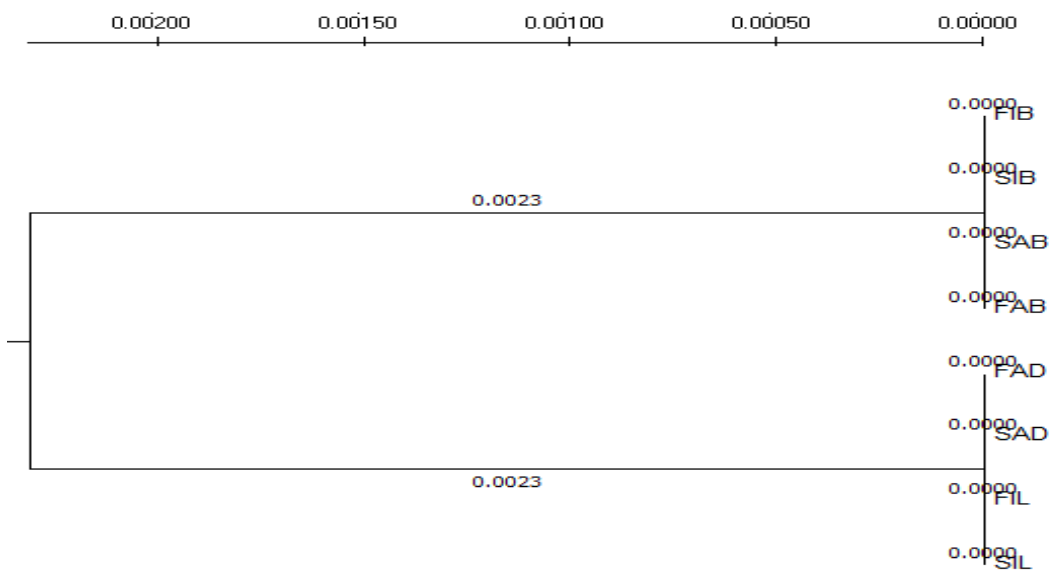

Figure 4. Genetic relationship among different populations of $C$. gariepinus using RAPD analysis.

respectively (Popoola, et al., 2014). In this study, the levels of significance of genetic variability among regions $\left(\Phi_{\mathrm{PR}}=0.01\right)$ indicated that the four sampled populations were significantly different from each other at $\mathrm{P}=0.01$, but not at higher probability levels. Pair wise population matrix of Nei's genetic distance obtained after analysing RAPD bands gave the extent of gene differences among populations. The index was used to construct a dendrogram which summarized evolutionary relationships among the populations into two clades. Also, a number of studies on genetic relationship had been done on fish, one of these include Ogbuebunu \& Awodiran (2017) on the genetic relationship among three populations of Lates niloticus depicted by UPGMA dendrogram. In the present study, the two clades formed by the UPGMA dendrogram showed that populations sampled from Ibadan and Abeokuta were more closely related than those obtained from Ado-Ekiti 
and Ile-Ife. Also, the two different strains obtained from the same location were more related than the others. This relation follows geographical distance. A similar report had been made by Saad et al. (2009) on some of the populations of $C$. gariepinus obtained from the wild.

Analysis of Molecular Variance (AMOVA) has been commonly employed for hierarchical analysis of the genetic differentiation among populations (Wollebaek, Heggenes \& Roed, 2011). In this study, the levels of significance of genetic variability among regions indicated that the four sampled fast- and slow-growing populations of adult C. gariepinus were significantly different from each other. This is similar to the report of Awodiran and Afolabi (2018) on the AMOVA for RAPD marker analysed on wild and cultured populations of $C$. gariepinus which indicated significant difference $(P=0.01)$ between the two populations. Evaluation of the distribution of molecular variation by AMOVA which also illustrated that most of the total genetic variance was found within strains was similar to Ribolli, Rodrigues de Melo and Zaniboni-Filho (2012) who reported that several individuals belonging to a particular population were attributed to other populations.

In conclusion, it was validated in this study that RAPD markers can evaluate genetic variability within cultured populations of $C$. gariepinus. This has corroborated the existing information regarding the need for determining genetic variation and population structure of the stocks of $C$. gariepinus in advance before commencing on breeding programmes. However, markers such as microsatellite DNA can be assayed in further studies for better results.

\section{Acknowledgment}

The authors thanked Afolabi O. for his assistance on the DNA analyses.

\section{References}

Awodiran, M.O. \& Afolabi, O. (2018). Genetic diversity in cultured and wild population of Clarias gariepinus (Burchell, 1822) in Nigeria Using Random Amplified Polymorphic DNA (RAPD) and Microsatellite DNA. Fisheries and Aquaculture Journal, 9: 247. https://doi:10.4172/2150-3508.1000247

Coulo, M.M.B., Vessen, J.M.B.M., Hofstra, H., \& Huisveld, J.H.J. (1994). RAPD analysis: a rapid technique for differentiation of spoilage yeasts. International Journal of Food Microbiology, 24(1): 249-260

Dale, J.W., \& Park, S.F. (2004). Molecular Genetics of Bacteria (4th Edition). John Wiley and Sons Ltd, England. 346 pp.

Danish, M. \& Singh, I.J. (2018). Assessment of genetic diversity of two populations of catfish Clarias batrachus L. using random amplified polymorphic DNA (RAPD) markers. Journal of Pharmacognosy and Phytochemistry, 7(3): 2345-2352. http://dx.doi.org/10.22271/phyto

Dunham, R.A. (2011). Aquaculture and Fisheries Biotechnology: Genetic Approaches. Second Edition. CAB International, Wallingford, UK. $495 \mathrm{pp}$.

El-Mogy, M., Simkin, M., \& Haj-Ahmad Y. (2016): Comparative study of DNA isolated from increasing volumes of blood using Norgen's blood genomic DNA isolation kit versus Qiagen's QIAamp DNA blood mini kit. Norgen Biotechnology Corporation: Application Note 59 Blood DNA Preparation. Pp. 1-3.

Freyhof, J. (2014). Clarias gariepinus. The IUCN Red List of Threatened Species 2014: e.T166023A1106307. https://dx.doi.org/10.2305/IUCN.UK.2014-

1.RLTS.T166023A1106307.en. Downloaded on 12 June 2020.

Ikpeme, E.V., Udensi, O.U., Ekaluo, U.B., Kooffreh, M.E., Okolo, C.M., Ekpo, P.B. \& Ogbonna, N.C. (2015). Unveiling the genetic diversity in Clarias gariepinus (Burchell 1822) using Random Amplified Polymorphic DNA (RAPD) fingerprinting technique. Asian Journal of Animal Sciences, 9: 187-197. https://doi:10.3923/ajas.2015.187.197

Karami, A., Goh, Y.M., Jahromi, M.F., Lazorchak, J.M., Abdullah, M., \& Courtenay, S.C. (2016). Diploid and triploid African catfish (Clarias gariepinus) differ in biomarker responses to the pesticide chlorpyrifos. The Science of the Total Environment, 557-558:204-211. https://doi:10.1016/j.scitotenv.2016.03.030

Legendre, M., Teugels, G.G., Cauty, C. \& Jalabert, B. (1992). A comparative study on morphology, growth rate and reproduction of Clarias gariepinus (Burchell 1822), Heterobranchus longifilis Valenciennes, 1840 and their reciprocal hybrids (Pisces, Clariidae). Journal of Fish Biology, 40:59-79. https://doi.org/10.1111/j.10958649.1992.tb02554.x

Liu, Z.J., \& Dunham, R. (1998). Genetic Linkage and QTL Mapping of Ictalurid Catfish. Circular Bulletin 321. Alabama Agricultural Experiment Station, Auburn University, Auburn, Alabama. 19 pp.

Lodish H., Berk A., Kaiser, C.A., Krieger M., Bretscher A., Ploegh H., Martin, K.C. (2016). Molecular Cell Biology. 8th Edition, W.H. Freeman and Company, USA. Pp. 1170.

Ogbuebunu, K.E., \& Awodiran, M.O. (2017). Molecular Characterization of Lates niloticus (Perciformes, Latidae) Populations from Tree Nigerian Waterbodies using Random Amplifed Polymorphic DNA and Microsatellite Markers. Vestnik zoologii, 51(1): 31-36. https://doi:10.1515/vzoo-2017-0005

Okomoda, V.T., Aminath L., Oladimeji S.A., Abol-Munaf, A.B., Korede, A.I., Ikhwanuddin Mhd, Shahreza, S.M. (2020). First Report on Successful Triploidy Induction in Clarias gariepinus (Burchell, 1822) Using Electroporation. Scientific Reports, 10: 2425. https://doi.org/10.1038/s41598-020-59389-2

Okomoda, T.V., Koh, I.C.C., Hassan, A., Amornsakun, T., \& Shahreza, S.M. (2018). Morphological characterization of the progenies of pure and reciprocal crosses of Pangasianodon hypophthalmus (Sauvage, 1878) and Clarias gariepinus (Burchell, 1822). Scientific Reports, 8(1):3827. https://doi:10.1038/s41598-018-22149-4

Ola-Oladimeji F.A. (2015). Comparison of Fitness Traits between Reciprocal Hybrids and Parentals of Clarias gariepinus (Burchell, 1822) and Heterobranchus bidorsalis (Geoffroy Saint-Hilaire, 1809). IOSR Journal of Pharmacy and Biological Sciences, 10(5): 78-82. https://doi:10.9790/3008-10527882

Ola-Oladimeji, F.A., Idowu, E.O., Adewumi, A.A., \& Fafowora, K.C. (2018). Heterogeneity Studies of Wild Clarias gariepinus (Osteichthyes, Clariidae) Using SDSPolyacrylamide Gel Electrophoresis. Vestnik Zoologii, 52, 
457 - 462. https://doi:10.2478/vzoo-2018-0047

Ola-Oladimeji, F.A., Oso, J.A., Oladimeji, T.E., Idowu, E.O., Adeleke, K. \& Urihe, F.O. (2017). Phenotypic diversities of four populations of Clarias gariepinus (Siluriformes, Clariidae) obtained from Ogun and Ondo State waterbodies in Southwestern Nigeria. Vestnik zoologii, 51(4): 285-294. https://doi:10.1515/vzoo-2017-0034.

Olaniyi, W.A. \& Omitogun, O.G. (2012). Induction of diploid gynogeneic larvae of African catfish, Clarias gariepinus Burchell 1822. Ife Journal of Agriculture, 25:73-82.

Peakall, R. and Smouse, P.E. (2006). GenAlEx 6: Genetic analysis in Excel. Population genetic software for teaching and research. Molecular Ecology Notes, 6(1): 288-295.

https://doi.org/10.1111/j.1471-8286.2005.01155.x

Peakall, R. and Smouse, P.E. (2012). GenAIEx 6.5: Genetic analysis in Excel. Population genetic software for teaching and research- an update. Bioinformatics, 28: 2537-2539.

https://doi.org/10.1093/bioinformatics/bts460

Popoola, O.M., Fasakin, E.A., \& Awopetu, J.I. (2014). Genetic variability in cultured and wild populations of Clarias gariepinus (Osteichthys: Clariidae) using Random Amplified Polymorphic DNA (RAPD) marker. Croatian Journal of Fisheries, 72(1): 5-11.

Ribolli J., Rodrigues de Melo, C.M. and Zaniboni-Filho, E.
(2012). Genetic characterization of the Neotropical catfish Pimelodus maculates (Pimelodidae, Siluriformes) in the Upper Uruguay River. Genetics and Molecular Biology, 35 (4): 761-769 https://doi:10.1590/S141547572012005000060

Saad, Y.M., Hanafi, M.S., Essa, M.A., Guerges, A.A., \& Ali, S.F. (2009). Genetic signatures of some Egyptian Clarias gariepinus populations. Global Veterinaria, 3(6): 503508.

Skelton, P. (2001). A Complete Guide to the Freshwater Fishes of Southern Africa. Struik Publishers, Cape Town. 395 pp.

Williams, J.K.F., Kubelik, A.R., Livak, K.G., Rafalski, J.A., \& Tingey, S.V. (1990). DNA polymorphisms amplified by arbitrary primers are useful as genetic markers. Nucleic Acids Research, 18:6531-6535. https://doi:10.1093/nar/18.22.6531

Wollebaek, J., Heggenes, J. and Roed, K.H. (2011). Population connectivity: Dam migration mitigations and contemporary site fidelity in Arctic char. BioMed Central Evolutionary Biology, 11:207.

Zheng, X., Cheng, T., Yang, L., Xu, J., Tang, J., Xie,...Hu, Z. (2019). Genetic Diversity and DNA Fingerprints of Three Important Aquatic Vegetables by EST-SSR Markers. Scientific Reports,9:14074. https://doi:10.1038/s41598019-50569-3 